\title{
Genetic diversity of two perch Perca fluviatilis populations of the Latgale region
}

\author{
Oksana Fokina, Dace Grauda, Isaak Rashal \\ Institute of Biology, University of Latvia, Address: Miera Str. 3, Salaspils, LV-2169, Latvia
}

\begin{abstract}
Molecular markers based on retrotransposons possibility of integration into genomes of many organisms are commonly used for genetic analysis of different species. The aim of this study was to test the possibility of use those markers in perch and detect the genetic diversity of populations of two lakes of the Latgale region of Latvia: Cirišs and Sventes. The distance between the lakes is nearly $60 \mathrm{~km}$, they belong to the same Daugava River basin but are different from the ecological point of view. Forty-two blood samples of Perca fluviatilis were collected altogether. Extracted DNA was analyzed using inter-PBS amplification technique with specifically selected retrotransposonbased primers and agarose gel electrophoresis. Data of genetic diversity of lakes were calculated by POPGENE and NTSYS software. In total, 127 loci were found in two populations, 81 of them were polymorphic. In spite of the rather small distance between lakes Cirišs and Sventes, several differences in genetic variation of populations of two lakes were found. For example, the number of polymorphic loci in samples from Lake Sventes was 61, but only 47 from Lake Cirišs. A unique allele was found in Lake Sventes. Genetic similarity and distance between populations of lakes Cirišs and Sventes was 0.9288 and $\mathbf{0 . 0 7 3 9}$, respectively. The results proved that molecular markers based on retrotransposons PBS regions can be very useful to test the genetic diversity of fish populations.
\end{abstract}

Keywords: iPBS, Perca fluviatilis, perch, retrotransposon-based molecular markers.

\section{INTRODUCTION}

Molecular markers based on retrotransposons integration into genome are universal, informative and rather easy for analysis, therefore they become very popular for investigation of the genetic diversity of many organisms. There are a lot of publications about genetic particularities of populations of some animals, plants and yeasts using retrotransposon-based molecular markers like REMAP (RetrotransposonMicrosatellite Amplified Polymorphism), SSAP (Sequence Specific Amplified Polymorphism), RBIP (Retrotransposon-based Insertion Polymorphism), and IRAP (Inter Retrotransposon Amplified Polymorphism) [1]-[6] but only limited information is available about retrotransposon-based markers in fish.

Molecular markers give an opportunity to compare genetic particularities of different populations which usually are not revealed by phenotypic characteristics. Possible genetic differences could be related with the history of populations and with differences of ecological conditions of their locations. From this point of view, it is interesting to compare populations of two lakes, Cirišs and Sventes, located in the Latgale region of Latvia [7]. Although the distance between the lakes is only about $60 \mathrm{~km}$ and both lakes belong to the same Daugava River basin, the environmental conditions of these lakes are different. Lake Sventes is one of top ten deepest lakes in Latvia, the average depth throughout the area of the lake is $7.8 \mathrm{~m}$, but in some places it reaches even 38 meters. In opposite, Lake Cirišs is not so deep: the maximum depth of Lake Cirišs is approximately 10 meters. Total areas of lakes Sventes and Cirišs are 7348 and $6306 \mathrm{~km}^{2}$, respectively. Lake Sventes contains as many as 7 species of fish, however in Lake Cirišs more than 10 fish species were found. The goal of this study was to look for the possibility of using IRAP method for genetic analysis of perch Perca fluviatilis and compare the genetic diversity of perch populations of both the above mentioned Latgale lakes.

\section{MATERIALS AND METHODS}

In 2011, fish blood samples were collected from the two lakes of the Latgale region of Latvia (Figure 1), altogether 42 samples: 22 from specimens of Lake Cirišs and 20 - from specimens of Lake Sventes. DNA from blood samples was extracted using Fermentas Genomic DNA Purification Kit. DNA extraction method was based on the Fermentas (ThermoScientific) protocol (thermoscientificbio.com/ fermentas/). Extracted DNA was electrophoresed for quality testing on a $1.7 \%$ agarose gel at $80 \mathrm{~V}$ for two hours. For most appropriate primers screening for IRAP analysis of Perca fluviatilis universal retrotransposon-based primers were applied [1]. Primers sequences selected for the investigation were: 2080 - CAGACGGCGCCA, $2081-$ GCAACGGCGCCA, - 
ACCTAGGCTCGGATGCCA [4]. PCR reaction consisted of 32 cycles. The first cycle at $95{ }^{\circ} \mathrm{C}$ for 3 min, 30 cycles at $95{ }^{\circ} \mathrm{C}$ for $30 \mathrm{~s}$, at $50{ }^{\circ} \mathrm{C}$ for $40 \mathrm{~s}$, at $68{ }^{\circ} \mathrm{C}$ for $1 \mathrm{~min}$, and the last cycle at $72{ }^{\circ} \mathrm{C}$ for 10 min. Total mix volume was $25 \mu l$. Amplified fragments were electrophoresed on $1.7 \%$ agarose gel for 15 hours at $50 \mathrm{~V}$ and stained with ethidium bromide, then documented with Transiluminators UViTEC STX 20M (Uvitec Limited, UK) and Digital photosystem MultiDOC DJ-HD (Cleaver, UK). Genetic characteristics of populations were calculated by Popgene and NTSYSpc 2.1 software. Principal coordinates analysis or Classical Multidimensional Scaling was calculated and matrix plot based on genetic distance matrices was generated using DCENTER and EIGEN.

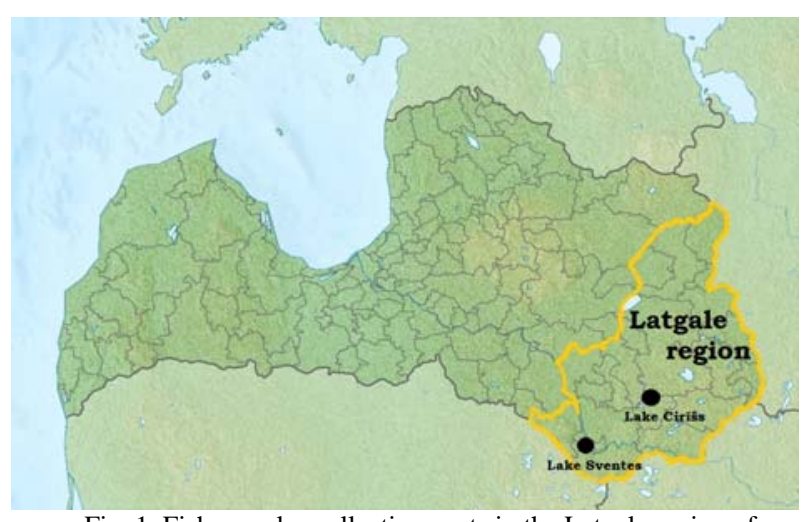

Fig. 1. Fish samples collection spots in the Latgale region of Latvia.

\section{RESULTS AND DISCUSSION}

Forty-two samples were analyzed using the IRAP method with three specific retrotransposon-based primers: 2080, 2081, and 2239. The selected primers showed good applicability for analysis of perch genetic polymorphisms: 50 loci were revealed by the primer 2080, 42 loci - by primer 2081, and 35 loci by primer 2239 (Figure 2). In total, 127 loci were found in the two populations using the IRAP method, 81 of them were polymorphic (64\%). The number of polymorphic loci in the population of Lake Cirišs was 47 (37\%), in the population of Lake Sventes almost half of loci - 61 (48\%) were polymorphic. A unique allele 2080_18 was found in three specimens from 20 of Lake Sventes (Fig. 2).

Genetic similarity between Perca fluviatilis populations of the lakes Sventes and Cirišs was 0.9261 , accordingly genetic distance between them was 0.0768. By using different types of markers small genetic differences between perch populations were also detected in Switzerland, Poland, and Italy lakes. Nei`s genetic distances between 27 allozymes from 136 fish specimens of four Swiss lakes (Lake Constance, Lake Zürich, Lake Geneva, and Lake Maggiore) was small (0-0.003), despite that these lakes belong to different drainage systems [8]. For analysis of the genetic diversity of perch from Central Poland differences in sequences in cytochrome $b$ gene and $D$-loop region of mitochondrial DNA were used. Data showed that nucleotide divergence based on haplotype frequencies varied in the range of $0-0.128$ and nucleotide diversity within populations from reservoirs with different size, ecological parameters and even age of construction also were low: 0.0030.02 [9]. Sequencing and RFLP (Restriction Fragment Length Polymorphism) method was used to find genetic diversity in mitochondrial DNA of five different perch species from Italy, however, only five different haplotypes were found [10].

All specimens from both populations of two lakes of Latgale region could be grouped into two clearly different clusters (Figure 3). Specimens from Sventes population were situated more diverse, which can be explained by a higher number of polymorphic loci in comparison with Cirišs population (61 and 47, respectively).

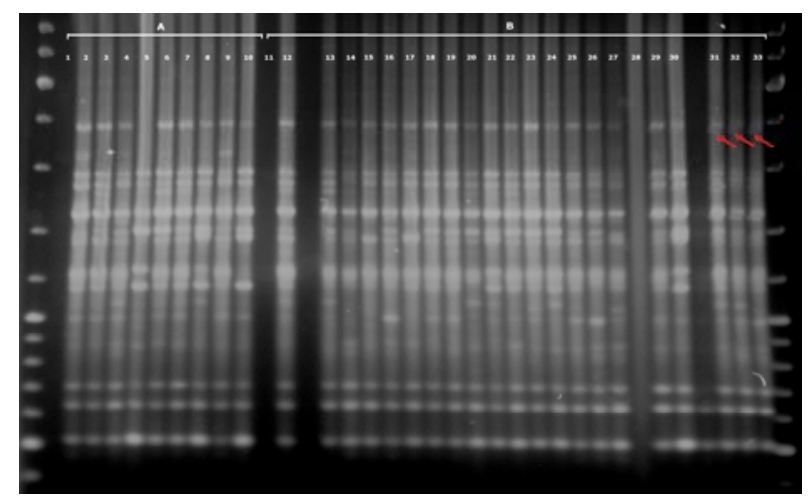

Fig. 2. Agarose gels after PCR amplification with primer 2080. (A) 2-10, specimens of Lake Cirišs; (B) 12-33, specimens of lake Sventes; 1 and 11 - the negative controls. The unique allele 2080_18 in three specimens is marked with the red arrows.

\section{CONCLUSION}

The IRAP method like other retrotransposon-based molecular marker systems could be very useful for analysis of genetic diversity of many organisms, including perch Perca fluviatilis. Specimens from the lakes Sventes and Cirišs of the Latgale region form two different clusters according to the IRAP molecular markers. Comparison our results with results of others studies across the Europe lead to conclusion that genetic differences are not related to geographical distances but probably depend on some ecological characteristics. Investigations of the influence of the ecological factors on the genetic diversity of perch populations including other Latvian lakes are in progress. 


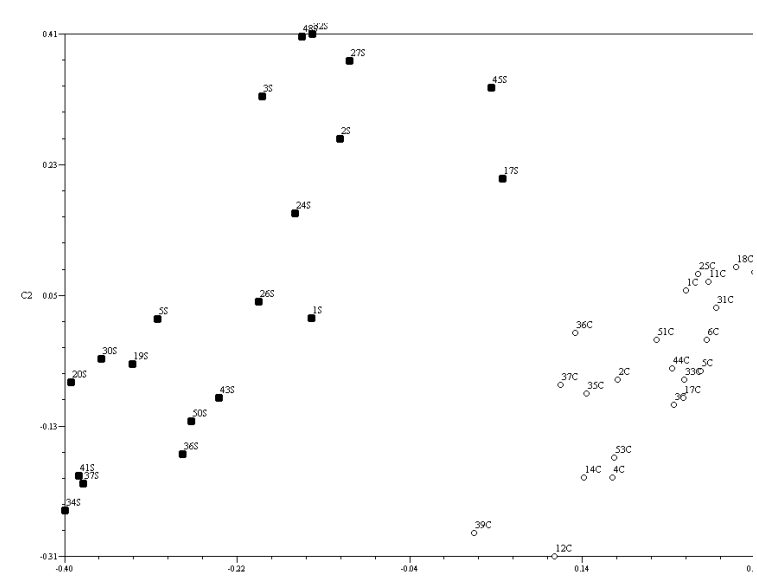

Fig. 3. PRINCIPAL COORDINATES ANALYSIS OF TWO POPULATIONS OF PERCA FLUVIATILIS FROM TWO LAKES OF LATGALE REGION OF LATVIA WAS BASED ON GENETIC DISTANCE MATRICES AND WAS GENERATED USING DCENTER AND EIGEN FUNCTIONS OF NTSYS SOFTWARE. SPECIMENS OF SVENTES POPULATION WERE MARKED WITH BLACK SQUARES, SPECIMENS OF CIRIŠS POPULATION - WITH WHITE CIRCLES.

\section{REFERENCES}

[1] Kalendar R., Schulman A. H. IRAP and REMAP for retrotransposon-based genotyping and fingerprinting. Nature Protocols 1, 5. 2006, pp. 2478-2484.
[2] Todorovska E. Retrotransposons and treir role in plantgenome evolution. Biotechnology and Biotechnological Equipment, 21. 2007, part 3.

[3] Agarwal M., Shrivastava N., Padh H. Advances in molecular marker techniques and their applications in plant science. Plant Cell Reports, 27. 2008, pp. 617-631.

[4] Kalendar R., Antonius K., Smykal P., Schulman A. H. iPBS: a universal method for DNA fingerprinting and retrotransposon isolation. Theoretical and Applied Genetics, 121, 8. 2010, pp. 1419-30.

[5] Kalendar R., Flavell A. J., Ellis T. H., N., Sjakste T., Moisy C., Schulman A. H. Analysis of plant diversity with retrotranspozon-based molecular markers. Heredity. 2010, pp. $1-11$.

[6] Monden Y., Yamaguchi K. , Tahara M. Application of IPBS in high-throughput sequencing for the development of retrotransposons-based molecular markers. Current Plant Biology, 1. 2014, pp. 40-44.

[7] Online database "Latvijas ezeri" [Latvian lakes]. Available: http://www.ezeri.lv/database/.

[8] Heldstab H., Katoh M. Low genetic variation in perch (Perca fluviatilis L.) from three major European drainage systems in Switzerland. Aquatic Sciences, 57, 1. 1995, pp. 14-19.

[9] Mankiewicz-Boczek J., Imsiridou A., Kaczkowski Z., Tsiora A., Karaiskou N., Lapinska M., Minos G., Zalewski M. Genetic diversity of perch populations in three lowland reservoirs (Central Poland): perspective for fish sustainable management. Pol. J. Ecol., 61, 2. 2013, pp. 385-390.

[10] Billington N. Genetic variation in percids determined by mitochondrial DNA analysis. Italian Journal of Zoology, 65, 1. 1998, pp. 35-40. 